City University of New York (CUNY) CUNY Academic Works

2013

\title{
Like a Hurricane: A Citation Analysis of Emergency Management Scholarly Literature
}

Jennifer Noe

CUNY Kingsborough Community College

Julia M. Furay

CUNY Kingsborough Community College

\section{How does access to this work benefit you? Let us know!}

More information about this work at: https://academicworks.cuny.edu/kb_pubs/3

Discover additional works at: https://academicworks.cuny.edu

This work is made publicly available by the City University of New York (CUNY).

Contact: AcademicWorks@cuny.edu 


\title{
This document is the final post-refereed draft of this article. The recommended citation for "Like a Hurricane" is as follows:
}

Noe, Jennifer, and Julia Furay. "Like a hurricane: a citation analysis of emergency management scholarly literature.” Community \& Junior College Libraries 19.1-2 (2013): 21-50.

\section{Like a Hurricane:}

\section{A Citation Analysis of Emergency Management Scholarly Literature}

\author{
JENNIFER NOE \\ Kingsborough Community College/CUNY, Brooklyn, New York \\ JULIA FURAY \\ Kingsborough Community College/CUNY, Brooklyn, New York
}

This bibliometric study used citation analysis to uncover citing characteristics in the burgeoning academic field of emergency management. Of the 281 degree programs listed by the Federal Emergency Management Agency nationwide, those at community colleges accounted for 17 percent of the total. Using the interdisciplinary database of Academic Search Complete, a sample of 5,099 citations was collected from 146 articles published between 2002 and 2012. The most strongly represented disciplines revealed by the analysis were Social Science, Science/Technology and Medicine. A majority of citations (45\%) came from academic journals, with nearly half (44\%) of those from Social Science. When citing outside of their discipline, medical and science/technology journals cited most often from Social Science, 70\% and 12\%, respectively. This study also finds the 20 most frequently cited journals, which will be of help to collection development and subject librarians.

KEYWORDS citation analysis, emergency management, hurricane, Katrina, interdisciplinary, 


\title{
Like a Hurricane: A Citation Analysis of Emergency Management Scholarly Literature
}

\author{
Framing the Issue
}

In 2005, the Gulf Coast of the United States was hit by three of the most powerful storms in U.S. history: Hurricanes Katrina, Rita and Wilma - all Category 5 events. It was the most active period of hurricanes in the Atlantic since record keeping began in 1851 (Gall and Cutter 2012). Hurricanes are particularly devastating natural disasters, accounting for the majority of losses due to catastrophe in the developed world (Emmanual and Sundararajan 2008). They have the potential for widespread destruction of densely populated areas and can wreak havoc over hundreds of miles. Moreover, they can be the cause - as was the case in Rita - of other devastating weather phenomena, such as tornadoes, in areas only marginally touched by the precipitating event (National Oceanic and Atmospheric Administration 2004). Global climate change and its potential to affect the frequency and severity of hurricanes is the subject of fierce debate today in the overlapping spheres of science, politics and the media (Curry, et al 2006).

The emergency management profession is tasked with coordinating and integrating any and all activities necessary in preparation for a natural disaster. In the aftermath of an event, it mitigates the impact through the reparation of degraded environments, the restoration of commerce and manufacturing, and the lessening the human suffering (Canton 2007). The field as we know it today has existed only since the mid-twentieth century. As an academic discipline, emergency management has existed for far less time than that. According to McGuire and Schneck (2010) those who filled emergency management positions prior to Katrina, Rita and Wilma in 2005 had "rather eclectic educational and professional backgrounds." In his research, Drabek (2007) noted that by 2006, there were 100 formal programs in emergency management with another 100 at various stages of development. In 2013, there were 281 educational 
programs at the doctoral, master's, and baccalaureate level, as well as bachelor-level concentrations and stand-alone certificate programs at colleges and universities across the country, including the University of Chicago, the John F. Kennedy School of Government at Harvard University and Tulane University. Programs at 46 community and junior colleges that offer associate degrees in the field account for 17 percent of the total listed by FEMA (Federal Emergency Management Agency 2013).

\section{Community College Emergency Management Programs at a Glance}

According to data provided by FEMA, Associate's Degrees in Emergency Management conferred from community colleges can be either Associate of Science (AS) or Associate of Applied Science (AAS) degrees. Though most community colleges offer a straightforward AAS in Emergency Management, many offer more specialized degrees, such as Homeland Security (Pikes Peak Community College), Emergency Preparedness Technology (Durham Technical Community College) and Technical Emergency and Disaster Management (Western Iowa Tech Community College). There is also a range in degree requirements: Whereas Red Rocks Community College confers an AAS in Emergency Management and Planning once students have completed 60 credits, Edmonds Community College requires between 95-99 credit hours to complete its AAS in Emergency Management and Business Continuity.

In addition to Associate's Degree options, many community colleges also offer certificate programs in various areas of emergency management such as Public Safety, Homeland Security, Emergency Management Planning and Administration, Crisis Management, and Disaster Services Technology. These certificates range in the number of credits required: From a ninecredit hour Emergency/Disaster certificate from Western Iowa Tech Community College to a 44credit hour certificate from Portland Community College (Federal Emergency Management Agency 2013). 
The following is a more in-depth look at the associate degree programs in emergency management at two community colleges and what they offer students.

Delaware County Community College in Pennsylvania has nine campuses in Delaware and Chester counties, serving approximately 28,000 students a year. According to enrollment data from the spring 2013 semester, more than half (63\%) of students attend part time. Delaware County offers 33 Associate’s degree programs, including an extensive one in Emergency Management and Planning (EMP) with concentrations in Fire Science, Law Enforcement and Emergency Medical. The program is housed under the auspices of the college's Division of Allied Health, Emergency Services, and Nursing. Thirty-five students were enrolled in the program during the spring 2013 semester, with the most - 19 - in the EMP Fire Science concentration, 17 in Law Enforcement and 9 in Emergency Medical (www.dccc.edu). Courses in the 61- to 62-credit curriculum includes Incident Management, Emergency Planning, Search and Rescue, and Leadership and Influence (www.dccc.edu).

The second largest junior college in its state, Community College of Vermont (CCV) has 12 campuses stretching from Bennington to St. Albans. It enrolls approximately 7,000 students each semester and offers 20 AS and AAS degrees; six Career Certificates, and transferable credits to Baccalaureate programs. Since 1975, the New England Association of Schools and Colleges has accredited CCV and in that time, the college has awarded 500 AS and AAS degrees. With an open admissions policy, CCV was ranked No. 1 for enrollment by Vermont high schools in a class of 2012 study. During the fall 2013 semester, CCV enrolled 6,631 students. Nearly all - 85\% - attended part-time. Some 93\% of graduates in the 2012 class reported being employed, continuing their education or serving in the military six months after earning their degrees (ccv.edu). 
The Emergency Management Program (EMP) began at CCV in 2009 and is one of 300 course curriculums the college has made fully available online. According to enrollment and graduation data, there have been a total of 71 students enrolled during the past five years' fall semesters - 40 men and 31 women. Required EMP classes are also offered in the spring and summer semesters. The fall 2013 semester had 13 students, all of whom took classes online. So far, EMP has awarded four AS degrees: two in 2011-2012, and two in 2012-2013 to two male recipients and two female (Diane Hermann, pers. comm.).

The 60-credit curriculum requires that students fulfill general education requirements and complete one course in each of several areas, including core competencies; areas of inquiry; integrative approaches; electives, and eight program requirement classes. These required classes include Principles of Emergency Management; Emergency Planning; Public Information Officer; Decision Making and Problem Solving in a Crisis, and Emergency Exercise Design and Evaluation. This last is described as a course that teaches students to assess the viability of a community’s emergency plan and its functionality through participation in management exercises and rehearsal of key responses (ccv.edu).

\section{Occupational-Professional Programs}

In their study of 20 growth fields in academia, including occupational-professional programs such as nursing, and computer and information science, Brint et al. (2011) found that high-enrolling institutions tended to be early adopters of these courses when they began appearing in the 1970s. These “academic omnivores” (2011) were more receptive than were wealthier universities and colleges, which tended to expand their offerings in the areas of arts and sciences. While emergency management was not among those studied by Brint and his colleagues, it certainly fits the description of an occupational-professional program, or one 
wherein graduates enter the field upon completion of their degrees. Brint and his colleagues note that new academic fields are rarely diffused "system-wide" (2011, 581). Indeed, only two in a group of 14 studied had spread to half of universities and colleges by 2005-2006 - computer and information science, and communications (2011). While that type of dissemination is still far beyond that achieved by emergency management studies, it has still grown surprisingly fast in the past decade, and as previously shown, since 2005.

\section{Emergency Management and Interdisciplinarity}

Scholarly articles on subjects that fall under the rubric emergency management are scattered throughout discipline-specific databases, including those as diverse from each other as environmental science and criminal justice. As yet, there is no database dedicated solely to the academic discipline of emergency management.

Like the story of the blind men and the elephant, emergency management can seem like a field composed entirely of hard sciences, such as engineering and physics, or social sciences, like sociology and public administration. In McEntire (2007), Ngo (2001) contends "ideally, disaster research is multidisciplinary and understanding the impact of disasters...requires a synthesis of various disciplines.” Gruntfest and Weber (1998) assert that emergency managers should be of no particular discipline and neither should the information they need by limited to the purview of one discipline (cited by McEntire, 2007). Little effort has been made to "tap the social sciences" as a way of deepening an understanding of the political, social and economic consequences of extreme natural disasters, according to Miletti (cited by McEntire 2007). McEntire asserts that integrating research from a number of different disciplines permits a "holistic understanding" of the type of "multifaceted" disaster events that mankind faces today (2007). 
While the discrete profession of emergency manager, one who coordinates the implementation of strategies designed to prepare for, protect against, recover from and mitigate against natural disasters, acts of terrorism and other man-made disasters, has been developing over time, it is only in the past decade that it has truly emerged (Dilling 2009). Acceptance by the public of a class of professionals working in all-hazard type crises has been elemental in the creation of this distinct field (Dilling 2009, Canton 2007). As Rubin notes: “Americans have come to regard emergency management as the quintessential public service...” $(2012,5)$.

As emergency management continues to grow as a professional career, so, too, does its viability as an academic subject and field of scholarly inquiry. As Dilling notes, curricula from higher education sources provide students with the scholarship they need to be the new generation of emergency management professionals (2009). Academics "generate, evaluate, organize and transfer knowledge” (2009) that must correspond closely to what emergency management practitioners consider the core understanding of the work and its values. Indeed, Dilling finds a high degree of congruence between emergency management academics and those working in the field with regard to what should be taught, regardless of discipline (2009). Moreover, she states that it “...would follow that the academic field of emergency management is strengthened by the very nature of its interdisciplinary character. Diversity is advantageous rather than fragmenting for this discipline. For undergraduate or graduate degrees, students should be, not just allowed, but encouraged or required, to take courses in other departments" (2009).

As Antell (2012) notes in her study of citations from the scholarly literature of LGBT Studies, highly interdisciplinary subjects can pose a challenge for collection development librarians who must select a host of resources to support the needs of faculty and students. 
Gerhard (2000) finds that researchers in interdisciplinary subjects face obstacles that include difficulties finding relevant documents and a lack of appropriate databases. Casting a wider net than scholars in traditional disciplines, researchers in interdisciplinary fields are likely to rely on published work from their home subject as well as that of other established disciplines, using explicit interdisciplinary resources if available (2000). Gerhard goes on to say that the development of interdisciplinary topics is less generated by new areas of specialization, but rather by the "meld[ing]" of older ones (2000, 52). Dobson (1996) and her colleagues find that scholars of interdisciplinary subjects are limited neither to one department nor to one college. While researchers and students may have a deep understanding of the core areas of their topic, “they may lack a broad understanding of the disciplinary field as a whole” (1996, 280).

Likewise, librarians, they noted, may find it difficult to build consensus among faculty dispersed through various institutions and disciplines as to what constitutes an "adequate local collection or adequate remote access” (1996, 280).

\section{Bibliometrics and Citation Analysis}

Rubin cites Wallace (1989) when he defines the field of bibliometrics as the study of information resources through the application of quantitative methods, or as a means of exploring "patterns in the production of knowledge as well as its use" (2010, 290). The term was coined in 1969 (Pritchard 1969), but the practice of bibliometrics had been developing for eighty years before that date (Osareh 1996). Originally a method of better understanding the sciences (Garfield 1977), bibliometrics has since been applied to a plethora of disciplines, “with applications in the history and sociology of knowledge, in communication and in library and information science” (Lawani 1981, 296). Citation analysis is an area of bibliometrics that uses the frequency and patterns of citations in articles and books through direct examination to, as a 
primary objective, identify which works and authors are most often cited in a particular discipline. Another major objective of citation analysis is determining the proportion and importance of various formats in a body of literature: for example, monographs as opposed to journals, government documents, grey literature, or other materials. A third research interest is the age of obsolescence (often called the "cited half-life") of a subject area or publication, which can be determined by examining the median age between publication and citation.

As a tool, citation analysis has numerous benefits. The identification of core journals and other works in a given area of study reveals influential works or authors who are likely to be requested by researchers (Rubin 2010). Additionally, determining what formats are predominant in a subject area can also provide statistical backing for funding and allocation decisions. Finally, weeding a collection may become easier once the date of obsolescence of a subject area or publication is determined (Rubin 1987). And yet citation analysis is also a tool with limitations. Chief among those limitations is that not all influential sources are cited, as an in-depth examination of biogeography citations revealed (MacRoberts and MacRoberts 2010). Additionally, the existence of a citation does not indicate the weight or importance of that citation to the citing work: "an item which was crucial to an entire research project looks the same as one of little value” (Broadus 1971, 237). Another potential problem is that citation analysis can only be as accurate as the citing work itself. For example, an examination of citations in surgical journals found that 48\% were incorrect (Evans, Nadjari and Burchell 1990), and a similar analysis of references in public health journals found 31\% to have citation errors (Eichorn and Yankauer 1987). Scholars may try to overcome these weaknesses by gathering a substantial number of citations for analysis (Broadus 1971). 
Emergency management as the subject of research in library science literature has been examined in a practical manner, perhaps as tips or in a lessons-learned type format. There has been no previously published study that analyzed the citations of scholarly literature for this particular field. Citation analysis as a methodology has been used, however, to examine other highly interdisciplinary subjects, notably library and information science (Chang and Huang 2012), international relations (Zhang 2008), and LGBT studies (Antell 2012). Scholars have also examined interdisciplinary subjects in a broader capacity: Levitt, Thelwall and Oppenheim (2011) examined 14 subjects in the Social Science Citation Index and by using the percentage of cross-disciplinary citing documents to evaluate the median level of interdisciplinarity found that it declined from 1980 to 1990, but rose sharply between 1990 and 2000. The SSCI subject with the largest increase in interdisciplinarity between 1990 and 2000 was Information Science and Library Science (LIS). Chang and Huang found that researchers in the LIS field most frequently cite publications in that subject. Moreover, half of all co-authors of such articles are affiliated with LIS-related institutes. Antell, in examining LGBT studies, found 33.2\% of citations were truly cross-disciplinary, as the citing journal and the cited article could be classified in different discipline categories (2012). Zhang, in analyzing international relations citations, found even higher levels of interdisciplinarity: approximately $62 \%$ of cited references derived from other disciplines (2008).

\section{A Brief History of Disasters and Disaster Management}

A disaster is a sudden, ruinous or calamitous event that brings great hardship (MerriamWebster). In the original sixteenth century Italian, a disastro meant "an unfavorable aspect of a planet or a star" (Oxford Dictionaries). While we no longer believe that an "obnoxious planet" 
caused a tsunami, natural disasters are still considered unfortunate occurrences over which humankind has no control.

At an estimated \$148 billion, Katrina was the costliest hurricane to ever hit the United States - even more costly than Hurricane Sandy in 2012 (New York Times; livescience.com). But it was not the most destructive. That honor goes to the Galveston Hurricane of 1900, a storm believed to have killed 6,000 people when it hit Galveston, TX, on September 8 of that year (National Oceanic and Atmospheric Administration, 2013). The United States has been recording a continuous chain of natural disasters in the forms of floods, hurricanes, blizzards, forest fires and earthquakes since the beginning of the nineteenth century (Christophe 2009). The twentieth century brought about a change in federal policy with regard to the management of catastrophes (Butler 2012). Events including the Galveston hurricane, earthquakes in San Francisco and Long Beach, CA, in 1906 and 1933, respectively, and the Great Influenza Pandemic of 1918 are what Butler refers to as “focusing events” $(2012,14)$. With each of these natural disasters, American policy moved toward the establishing of legislation that would mandate direct federal assistance for victims and clean up in the aftermath of the event.

\section{Civil Defense and the Creation of FEMA}

Prior to the mid-twentieth century, emergency management existed in an ad hoc way led by some federal agencies, as well as state and local governments. For much of that period, however, it was conducted by the American Red Cross (Rubin 2012). As Rubin notes, the history of disaster management is event driven, with major calamities like those mentioned earlier in this study bringing new knowledge, procedures, policies and legislation in their wake. Disaster management as we recognize it in the twenty-first century began in the 1950s, growing out of the Civil Defense era of WWII. The Civil Defense Act of 1950 focused on the role of national 
security in the wake of nuclear testing by the Soviet Union, and the Korean War. It defined the role of local government in disaster preparedness. The Act was later amended in 1976 to allow for the use of civil defense resources in all hazard situations, including disaster relief and recovery from natural disasters (Canton 2007). Between 1950 and 1979, when the Federal Emergency Management Agency (FEMA) was created by President Jimmy Carter, responsibility for disaster management was handled by a variety of different government agencies that oversaw a bounty of disaster relief programs, including the Federal Insurance Administration; the National Fire Prevention and Control Administration, and the Federal Disaster Assistance Administration. Ultimate accountability bounced from the Office of the President to the Department of Defense and back again to the White House (Canton 2007). These programs were ultimately absorbed by FEMA, which functioned as an independent administration whose directorship was a Cabinet position. In 2003, FEMA was put under the purview of the Department of Homeland Security (Sylves 2012).

\section{The Impact of Katrina}

"It is instructive to review how much has changed since 2005” (Rubin 2012, 2). Katrina, Rita and Wilma did as much for the field of natural disaster management as the attacks of Sept. 11, 2001 did for counterterrorism (2012). The flooding of New Orleans and other Gulf Coast cities by Katrina when it made landfall as a Category 3 hurricane at 6:10 AM in Plaquemines Parish, LA, on August 29, 2005, was one of the worst natural disasters in United States history. It was also one of the five deadliest hurricanes in the nation's history, killing 1,833 people. With winds of $125 \mathrm{mph}$ and rain that exceeded one inch per hour (National Oceanic and Atmospheric Administration 2005) at least 80 percent of New Orleans was under 20 feet of water by Aug. 31 . Much of the flooding came as a result of levees having failed to hold back the waters of Lake 
Pontchartrain and the Mississippi River. In addition, the cities of Gulfport and Biloxi, MS, were submerged after being hit by a 20- to 30-foot storm surge. Other regional municipalities, such as Mobile AL, were decimated by the surge from Mobile Bay (National Oceanic and Atmospheric Administration 2005). Katrina dropped between 10 and 14 inches of rain on Southern Florida, and unleashed 62 tornadoes in eight states from Mississippi to Pennsylvania.

Just two weeks later, Rita hit the Texas-Louisiana border on September 25, 2005. It was responsible for an estimated 90 tornadoes that swept through Alabama, Arkansas, Mississippi and Louisiana. Seven people were killed as a direct result of the storm (National Oceanic and Atmospheric Administration 2012). When Wilma struck on Oct. 24, 2005, a weather station in Lake Okeechobee, FL, reported an average of $92 \mathrm{mph}$ winds with a gust of $117 \mathrm{mph}$ in the city of Belle Glade. Twenty-two deaths have been directly attributed to Wilma, 5 of those in Florida. It caused an estimated $\$ 16.8$ billion in the southern portion of the state and spawned 10 tornadoes. The $882 \mathrm{mb}$ pressure reported in Wilma is the lowest central pressure on record in an Atlantic hurricane (National Oceanic and Atmospheric Administration 2012).

There is little argument that it was Katrina, however, that prompted a reevaluation of the nation’s disaster management practices (Moore, et al 2009). The official response to Katrina's devastation has been widely studied and criticized, but in brief, the federal government in the form of FEMA failed to provide a timely response. "The emergency response to Hurricane Katrina, which was so inadequate that government officials at every level were humiliated at home and abroad, prompted the deepest and most sustained examination of U.S. Emergency management functions and systems ever conducted” (Rubin 2012, 2).

\section{Collection Development}


As the number of academic institutions increase their offerings with regard to emergency management programs, it is crucial for collection development librarians to have an understanding and knowledge of what researchers and students in this new and highly interdisciplinary field are going to request. Given the potential for more and more violent hurricanes due to our changing climate, the number of emergency management certification, undergraduate and graduate programs will very likely continue to grow in the foreseeable future. With that in mind, the authors will answer the following questions:

- What sources are used most frequently in disaster management’s scholarly literature?

- Which journals were represented most frequently in the sample and by extrapolation are essential?

- What seem to be the core disciplines in the field? Among these, how much interdisciplinarity occurs?

- Range of years between publication and citation?

- Range of years among citations from oldest to most recent?

\section{Methodology}

This study uses direct citation analysis to examine the frequency and type of sources used in the scholarly literature of the emergency management field. The 146 articles in the study’s selected sample were collected from a multidisciplinary database and date from January 2002 through December 2012. A period of 10 years was chosen because it was necessary to show whether cited sources changed over that time, and if so, how they changed. That particular 10-year span was selected because it includes the year 2005, a year which is widely considered a watershed year for the profession of emergency management and one of the worst years for disasters in modern US history. Rubin contends that 2005 was the year that the emergency- 
management field became the all-hazard force we now recognized it to be (2012). Due to the multidisciplinary nature of crisis management, the sample was created from articles either contained or indexed by Academic Search Complete, an EBSCO database. By using this particular database, articles from a wide variety of academic disciplines could be included, and the risk of excluding important contributing fields to emergency management could be minimized. The topic search excluded terrorism or homeland security articles and narrowed results to hurricanes and the United States. Articles that fell outside of these parameters were rejected, as were editorials, reviews and other items that though appearing in academic journals were not scholarly communications, or did not include a reference list.

Bibliographic information including title, author, date and journal was collected for each article in the sample, which yielded 5,099 citations. These citations were then divided into format categories including books, journals, magazines, newspapers, websites, conferences, dissertations or gray literature, such as reports from non-profits agencies, colleges or think tanks, unpublished works and other types of documents that do not fit neatly into a particular category. A MS Excel spreadsheet was created that examined journal citations, assigning them disciplines based on subject headings used by Ulrichsweb. Each discipline - social science, science/technology, humanities, medicine and law - comprised a variety of different subjects that included biology, environmental science, psychology, pediatrics and criminal justice. The cited journals were also separated based on the frequency with which they appeared within the sample, their date of publication, and the date between the publication of the sample article and the cited journal. Several of these cited journals were dually assigned disciplines. An appendix contains a reference list of the citing articles in the sample. 
Of particular interest to the investigators was any change in these elements that could be attributed to the hurricanes that hit the nation’s Gulf Coast - Katrina, Rita and Wilma - in 2005. By examining these, it is possible to see how reactive the newly emerging field of emergency management is at this point in its development.

\section{Findings and Discussion}

\section{Diversity of Citations}

Nearly half of the 5,099 citations in the sample - 2,304 (45\%) - were composed of scholarly journal articles. The second most frequently used format was books, which accounted for 1,087 citations or $21 \%$ of the total. Together, these two publication types represented twothirds of the entire sample. As noted by Antell (2012), the high representation of journal articles and books in citation analyses that examine publication formats has been shown to be consistent by a number of different studies. But while Antell's findings placed the combined formats of journals and books at $80 \%$ or higher, the percentage of emergency management's journal and book citations came to $66 \%$. The lower proportion could be due to the percentage of the sample's total made up by government documents $-10.6 \%$ or 546 . Government documents was the third most frequent category of publication cited in this study.

In addition to documents from FEMA, other federal agencies were also cited by the sample articles. Such departments included the Drug Enforcement Administration; the Department of the Interior; the Centers for Disease Control and Prevention; the Environmental Protection Agency: Congressional Subcommittees; the U.S. Army Corps of Engineers; the White House; Executive Orders and the U.S. Geological Survey, among others. In addition, cited entries came from municipal, county and state governments, as well, such as state police agencies and local hurricane centers. There were also entries in the sample that cited documents 
from international governments, including those in Indonesia, Canada and Australia. Given the nature of emergency management and its relationship to FEMA and the NOAA in particular, amongst these other agencies, one may speculate that this might account for the smaller percentage of journal and book citations.

The other publication types tracked in the study represented far smaller slices of the pie: gray literature - 8.7\% (445), newspaper articles - 6\% (326) and websites - 4\% (203). The formats used least often were: proceedings from conferences - 1.8\% (94), magazines - 1\% (65) and dissertation/thesis - .57\% (29).

Those entries assigned to the gray literature category included papers published by the United Nations High Commissioner for Refugees and other United Nation's agencies, the World Hunger Organization, and the International Monetary Fund; non-profit groups such as Save the Children Fund and the Open Society Institute (now called the Open Society Foundations); and research from a variety of college and university centers including Marshall University's Center for Business and Economic Research, and the Social Science Research Center at Mississippi State University.

Frequently Cited Journals

The 20 most frequently cited journals in the sample, which made up one-fifth of all journal citation entries, come from three major disciplines relating to disaster management: Social Sciences (9), Science/Technology (7), and Medicine (4). The range of disciplines of these frequently cited journals affirms what a truly interdisciplinary field emergency management is. It also demonstrates the breadth of research documents and materials needed to be collected for use by students, faculty and researchers in this subject. The most cited journals in the 146-item sample were International Journal of Mass Emergencies and Disasters, with 38 entries, and 
Disasters, with 36. These were followed by Natural Hazards Review, with 35, and Science, with 33. Other cited journals with greater than 20 entries were: the Monthly Weather Review (33), the Journal of Personality and Social Psychology (29), the Journal of Contingencies and Crisis Management (28), the American Journal of Public Health (23), the New England Journal of Medicine (21), the Personality and Social Psychology Bulletin (21), and the Public Administration Review (21). The remaining journals, which had fewer than 20 entries, included: Prehospital and Disaster Medicine (19), JAMA: The Journal of the American Medical Association (18), Disaster Prevention and Management (17), Transportation Science (16) and Disaster Recovery Journal (15). The European Journal of Operational Research and the Bulletin of the American Meteorological Society each had 14 entries, as did Lancet and Nature. Core Subjects and Disciplines

With regard to core disciplines within this study’s sample, Social Sciences represented the greatest percentage of cited journals, accounting for 54\% of the total. The next most represented discipline was Science/Technology, which made up 27.6\%, and Medicine, which made up $15.5 \%$. Humanities and Law each made up less than $2 \%$ of the sample. There were six subjects which had over 100 entries: Medical Sciences (354); Psychology (261); Business and Economics (225); Public Health and Safety (175); Sociology (150) and Environmental Studies (142). In assigning disciplines using Ulrichsweb, this study puts Medical Sciences under Medicine, with Business and Economics, Public Health and Safety, Psychology and Sociology coming under Social Sciences. Environmental Studies is categorized under the discipline of Science/Technology. Based on this finding, one may assume that these are core disciplines and subjects in the emergency management field, and that they should be included in any print and 
digital resources acquired by collection development librarians to support emergency management curriculums. (see figures 1 and 2).

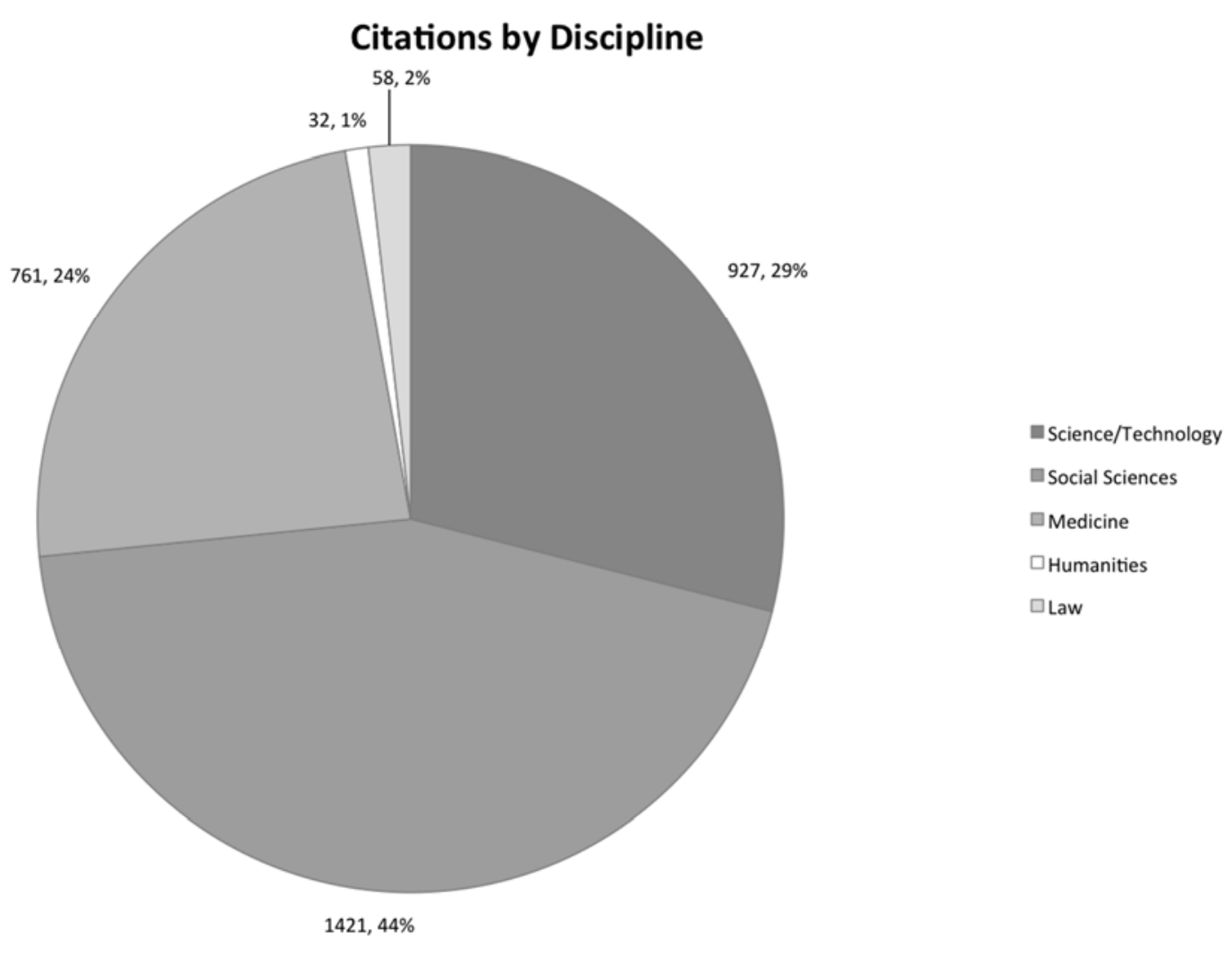

Figure 1: Core Disciplines in the Emergency Management Field.Note.Breakdowns of citations from each discipline examined in this sample.

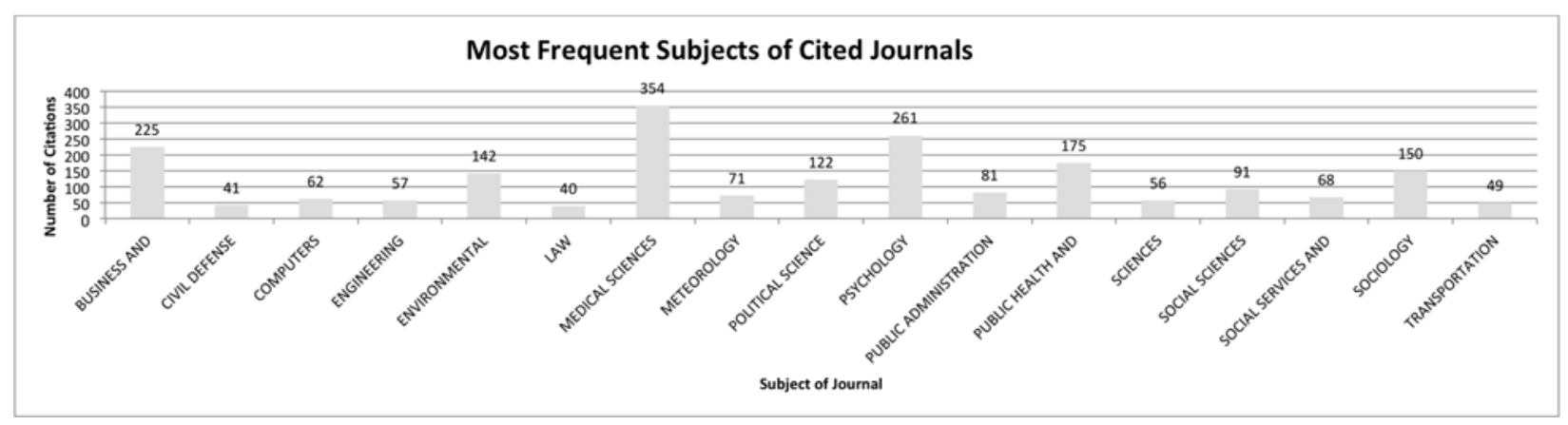

Figure 2 Core Subjects in the Emergency Management Field.Note. Represents the most frequent subjects of cited journals (as classified by Ulrichsweb). Chart represents only those subjects which had at least $\mathbf{4 0}$ citations. 


\section{Interdisciplinarity}

The authors investigated the discipline of the citing journal as compared to the journal citations to gauge the level at which interdisciplinarity occurs. Among the findings were that overall, $64 \%(1,477)$ of journal citations were within the discipline of the citing journal, with 36\%, (827), falling outside of the citing journal's discipline.

Focusing on Social Sciences, Medicine, and Science/Technology - those disciplines that made up the vast majority of citing journals - Social Sciences were found to have the greatest amount of interdisciplinarity, with 439 journal citations, or 41\%, of 1,066 total citations from Social Sciences journals attributed to disciplines outside the field. Of those, 269 (25\%) came from the discipline of Medicine, while less than half that number of citations, 123, or just $11.5 \%$, came from Science/Technology journals.

Citing journals within the discipline of Medicine had a similar proportion of interdisciplinary journal citations. Of 662 total citations from medical journals, 44\% (291) came from outside the discipline. Most of these - 203 citations (31\%) came from the Social Sciences. Some $12.5 \%$ (83) came from the discipline of Science/Technology.

Citing articles from the discipline of Science/Technology had the fewest interdisciplinary citations: just 97 (or 16.9\%) of 573 total citations came from an outside discipline. A majority of interdisciplinary citations found in Science/Technology journals -- 69, or $12 \%$ of all Science/Technology -- came from Social Sciences. Just 22 citations (4\%) came from journals classified under the discipline of Medicine.

Looking at interdisciplinary citations as a whole, the greatest overlap between disciplines seems to be between the Social Sciences and Medicine. While further research on why these two disciplines seem to be linked in this way is necessary, one might speculate that the medical needs 
of a population in the aftermath of a natural disaster such as a hurricane would inform the sociological, public policy, and psychological scholarly discussion on this topic.

\section{Range of Years Between Citation and Citing Publication}

This study considered the median age between journal citations and citing journals rather than the average so as to avoid skewed results based on an individual entry. The median age overall was six years. Median ages were also calculated for each of the 10 years of the sample. As shown in figure 3, the median age of citations grew more consistent after 2006. Prior to that, median ages ranged from 12 years in 2002 to six years in 2003, back to 11 years in 2004 and down to three years in 2005. With the exception of 2008, in which the median age was eight, the median age for each year between 2008 and 2012 was either five years or six years.

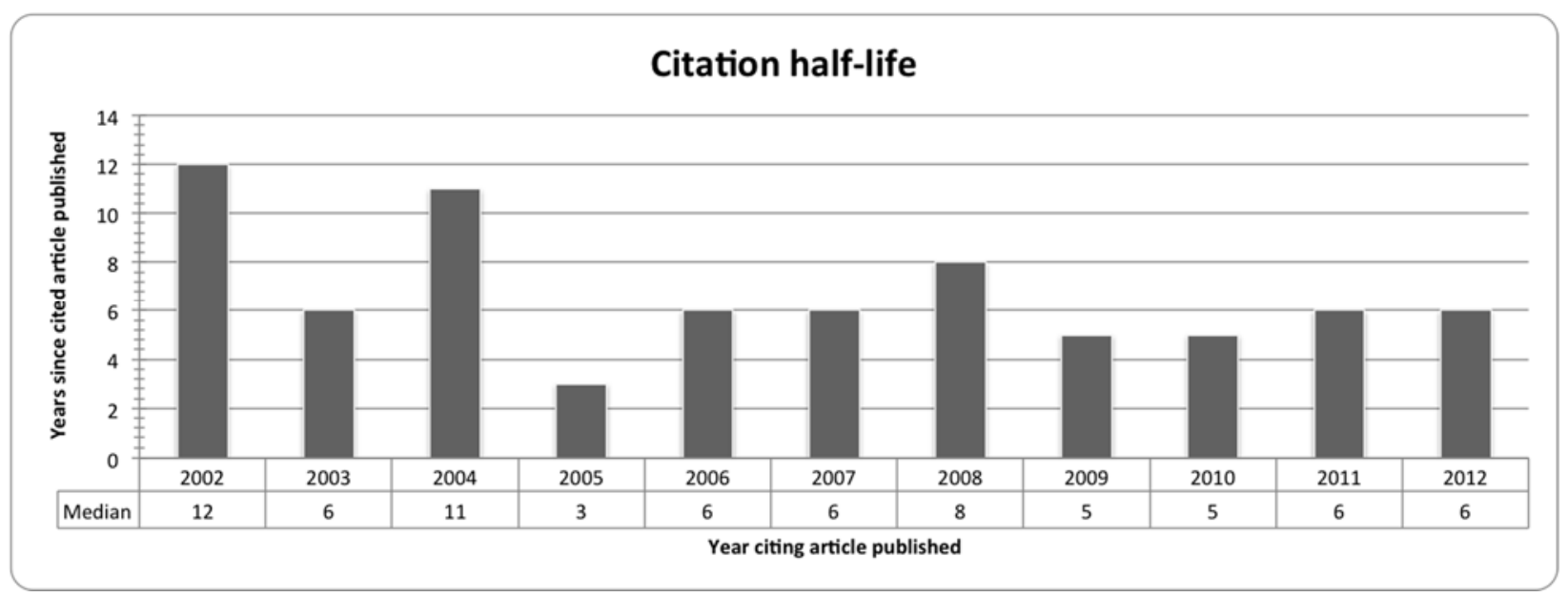

Figure 3 Median Age of Citations from 2002-2012.Note.Figure represents the median age between publication date of the cited article and publication date of the citing article for each year included in the sample. 


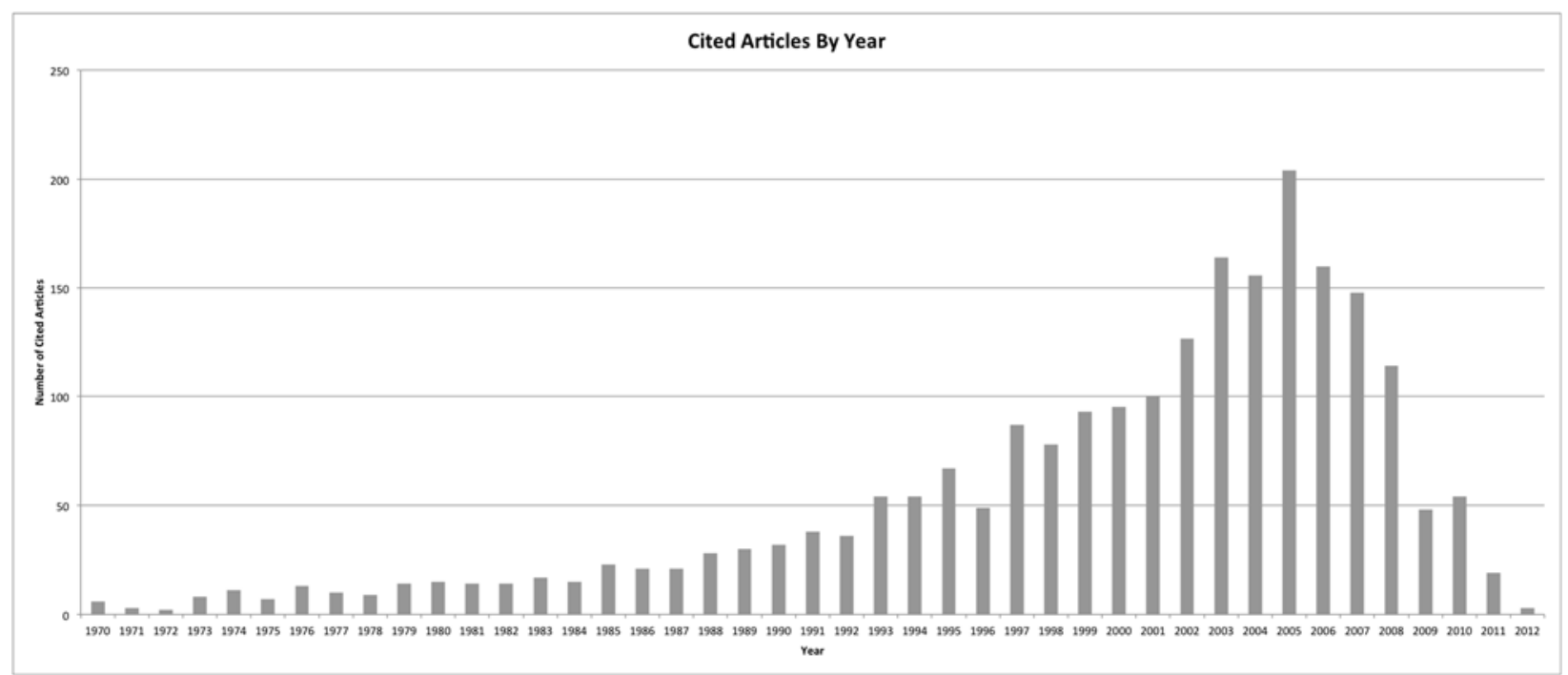

Figure 4 Annual Total Citations, 1970-2012.Note. The number of articles cited in the samplefor every year from 1970-2012.

Range of Journal Citation Years

The consistency of the median age of cited articles to journal articles within the last five years of the study’s range - 2008 through 2012 - is no doubt related to the abundance of scholarly communications that began appearing in 2005 and continued for some years following Katrina. In charting the publication years of cited articles from 1970 to 2013, it seems as though the field's scholarly literature were building toward this moment. One sees a marked rise in citation numbers after the turn of the century, peaking in 2005 (See figure 4). In 2001 the cited article count tops 100 for the first time, and the figure continues to climb in 2002 (127 cited articles) and 2003 (164 cited articles), while 2004, with 156 cited articles, dips only slightly. 2005 was the high water mark: the cited article count went as high as 204; the trend continued in 2006 with 160 cited articles, and 148 that dated from 2007. After this fertile period of discussion, the conversation slowed; 114 cited articles were published in 2008, dropping to less than half that in 2009 (48 cited articles) and 2010 (54 cited articles). Given these results, there can be little doubt that the events of Katrina, Wilma and Rita -- as well as earlier hurricanes such as Isabel in 2003 
and Ivan in 2004 -- deepened academic inquiry into the emergency management field and provided a wealth of new data for researchers in a host of subjects and disciplines.

This finding also points to how reactive the still-developing discipline of emergency management tends to be. Of 146 citing articles contained in the sample, only 17 were published prior to 2005, and just 6 have a publication date of 2005 -- this was particularly intriguing as this was the most prolific year for journal citations. While the number of citing journals jumped to 37 in 2006 and 22 in 2007, it fell again in the later years covered by this study. In 2011, there were only 18 articles published; in 2012, there were 11.

\section{Conclusion}

Journal articles made up the bulk of citations in this study’s sample - 45\%. Of that figure, nearly half - $44 \%$ - of cited journals fell under the discipline of Social Science. Librarians building a collection of resources to support an emergency management studies curriculum might want to focus their efforts on scholarly databases whose holdings draw deeply from subjects under that discipline. Social Science, along with Science/Technology and Medicine, were the most highly represented disciplines among the 20 journals most frequently cited in the study's sample. With nine of those 20 falling under Social Science, it had the greatest number of journals, as compared with Science/Technology’s seven and Medicine’s four.

With regard to interdisciplinarity, only approximately one-third of journal citations were outside the discipline of the citing journal. Yet the majority of interdisciplinary citations found in both Medicine and Science/Technology citing journals came from Social Science. Of a total of 662 journal citations from Medical journals, 44\% were interdisciplinary. Of these interdisciplinary citations, 70\% came from Social Science. In Science/Technology, which had a 
total of 573 citations, Social Science citations made up $12 \%$ of the $17 \%$ of interdisciplinary citations there.

The year 2005 was critical in the development of the academic field of emergency management, having the greatest number of cited articles appearing in the sample's academic journals. The years 2006 and 2007 had both the highest number of citing articles and the second and third largest numbers of cited articles. With 422 articles on emergency management and hurricanes between the years 2005 and 2007, this finding is a boon not only to collection development librarians but to any librarian helping patrons at the reference desk gather scholarly materials on this important subject.

The outsized role of the Social Sciences in emergency management’s academic literature was a surprise to these researchers. The discipline of Science/Technology had just two more subjects under its auspices - 34 - than did Social Science - 32. The presumption that emergency management as an academic field is dominated by the hard sciences is apparently wrong. Perhaps the number of citations from journals that examine the human side of disaster is due to Katrina, of us as a nation watching the desperation of victims trapped in a flooded and chaotic New Orleans and the indelible impression it could not help but make on us. As this study noted earlier, alleviating the suffering of communities devastated by hurricanes and other natural disasters has always been a part of emergency management, but it is only in the past few decades that it became the ultimate public service.

The discipline of emergency management is ripe for further research. One area that this study did not cover was the impact of Superstorm Sandy on the field's scholarly literature. One may surmise that the year 2012, like 2005 and the years immediately following Katrina, will provide a large number of academic articles, as well as other types of publications. It would be of 
interest, perhaps, to see what if any differences there are in the research subjects of citing and cited articles about Sandy as compared with Katrina. Whether, for example, disciplines in the Social Sciences still predominate with regard to journal articles, or, whether another discipline is more prominently represented, given the geographic and socio-economic differences between the Gulf Coast cities hit in 2005 and the major metropolitan centers of the East Coast affected by Sandy. 


\section{Figures and Tables}

Figure 1: Core Disciplines in the Emergency Management Field

FIGURE 1 Breakdown of citations from each discipline examined in this sample.

Figure 2: Core Subjects in the Emergency Management Field 
FIGURE 2 Represents the most frequent subjects of cited journals (as classified by Ulrichsweb). Chart represents only those subjects which had at least 40 citations.

\section{Figure 3: Median Age of Citations from 2002-2012}

FIGURE 3 Figure represents the median age between publication date of the cited article and publication date of the citing article for each year included in the sample.

Figure 4: Annual Total Citations, 1970-2012

FIGURE 4 The number of articles cited in the sample for every year from 1970-2012. 


\section{Reference list}

Antell, Karen. 2012. The Citation Landscape of Scholarly Literature in LGBT Studies: A Snapshot for Subject Librarians. College \& Research Libraries 73 (6) (November): 584-602. Accessed February 22, 2013.

Brint, Steven, Kristopher Proctor, Robert A. Hanneman, Kerry Mulligan, Matthew B. Rotondi, and Scott P. Murphy. 2011. Who Are the Early Adopters of New Academic Fields? Comparing Four Perspectives on the Institutionalization of Degree Granting Programs in US Four-Year Colleges and Universities, 1970-2005. Higher Education: The International Journal of Higher Education and Educational Planning 61 (5) (May 1): 563-585. doi.org.kbcc.ezproxy.cuny.edu:2048/10.1007/s10734-010-9349-z. Accessed May 30, 2013.

Broadus, Robert N. 1971. The Literature of the Social Sciences: a Survey of Citation Studies. International Social Science Journal 23 (2) (May): 236.

Butler, David. 2010. Focusing Events in the Early Twentieth Century: A Hurricane, Two Earthquakes, and a Pandemic. In Emergency Management: The American Experience, 19002010, $2^{\text {nd }}$ ed., ed. by Claire B. Rubin. 13-49. Boca Raton, FL: CRC Press.

Canton, Lucien G. 2007. Emergency Management: Concepts and Strategies for Effective Programs (Google eBook). John Wiley \& Sons: Hoboken, NJ.

Chang, Yu-Wei, and Mu-Hsuan Huang. 2012. A Study of the Evolution of Interdisciplinarity in Library and Information Science: Using Three Bibliometric Methods. Journal of the American Society for Information Science \& Technology 63 (1) (January): 22-33. doi:10.1002/asi.21649.

Christophe, Antoinette S. 2009. Managing Natural Disasters: Performance of Two National Disaster Management Agencies and One Major Non-profit Organization. PhD. Southern University and Agricultural and Mechanical College. Proquest (AAT 3460081).

Community College of Vermont. http://ccv.edu/learn-about-ccv/facts-figures. Accessed February 12, 2014.

Community College of Vermont.

http://catalog.ccv.edu/preview_program.php?catoid=3\&poid=72\&returnto=614. Accessed February 12, 2014.

Curry, J. A., Peter J. Webster, and Greg J. Holland. 2006. Mixing Politics and Science in Testing the Hypothesis That Greenhouse Warming Is Causing a Global Increase in Hurricane Intensity. Bulletin of the American Meteorological Society 87 (8) (August): 1025-1037. doi:10.1175/BAMS-87-8-1025. Accessed June 12, 2013.

Delaware County Community College. http://www.dccc.edu/institutional-effectiveness/institutionalreports. Accessed February 12, 2014. 
Delaware County Community College. http://www.dccc.edu/programs-study/careerdegree/emergency-management-and-planning-associate-applied-science. Accessed February 12, 2014.

Dilling, Janet. 2009. Locus of an Emergent Field: Framing Emergency Management Knowledge, Values, and Priorities Within Current Academic Curricula PhD Dissertation, The Florida State University. Proquest (AAT 304878951).

Dobson, Cynthia, and Jeffrey D. Kushkowski. 1996. Collection Evaluation for Interdisciplinary Fields: A Comprehensive Approach. Journal of Academic Librarianship 22 (4) (July): 279. http://ehis.ebscohost.com.kbcc.ezproxy.cuny.edu:2048/ehost/detail?sid=34112d2c-fb00-4178a68148c12c4ecf80\%40sessionmgr13\&vid=10\&hid=105\&bdata=JnNpdGU9ZWhvc3QtbGl2ZQ\%3d \%3d\#db=lih\&AN=9609113600. Accessed June 7, 2013.

Drabek, Thomas E. Emergency Management and Homeland Security Curricula: Contexts, Cultures, and Constraints. paper presented at the annual meeting of the Western Social Science Association, Calgary, Alberta, Canada, April, 2007.

Eichorn, Philip, and Alfred Yankauer. 1987. Do Authors Check Their References? A Survey of Accuracy of References in Three Public Health Journals. American Journal of Public Health 77 (8): 1011-1012.

Emanuel, Kerry, Ragoth Sundararajan, and John Williams. 2008. Hurricanes and Global Warming. Bulletin of the American Meteorological Society 89 (3) (March): 347-367. doi:10.1175/BAMS89-3-347. http://search.ebscohost.com/login.aspx?direct=true\&db=eih\&AN=31686534\&site=ehost-live . Accessed June 12, 2013.

Evans, James T., Howard I. Nadjari, and Sherry A. Burchell. 1990. Quotational and Reference Accuracy in Surgical Journals: A Continuing Peer Review Problem. JAMA 263 (10) (March 9): 1353-1354. doi:10.1001/jama.1990.03440100059009.

Gall, Melanie and Susan L. Cutter. 2012. 2005 Events and Outcomes: Hurricane Katrina and Beyond. In Emergency Management: The American Experience, 1900-2010, 2nd ed., ed. by Claire B. Rubin. 191-211. Boca Raton, FL: CRC Press.

Gerhard, Kristin H. 2000. Challenges in Electronic Collection Building in Interdisciplinary Studies. Collection Management 25 Issue 1/2, p51, 15p (1/2): 51. Accessed August 7, 2013.

Gruntfest, Eve and Marc Weber. 1998. Internet and Emergency Management: Prospects for the Future. International Journal of Mass Emergencies and Disaster 16(1): 55-72.

Huang, Mu-Hsuan, and Chang, Yu-Wei. 2012. A Comparative Study of Interdisciplinary Changes Between Information Science and Library Science. Scientometrics [0138-9130] 91(3) (June): 789. doi:10.1007/s11192-012-0619-7. August 7, 2013. 
Lawani, S. M. 1981. Bibliometrics: Its Theoretical Foundations, Methods and Applications. Libri 31 (1). doi:10.1515/libr.1981.31.1.294.

Levitt, Jonathan M., Mike Thelwall and Charles Oppenheim. 2011. Variations Between Subjects in the Extent to Which the Social Sciences Have Become More Interdisciplinary. Journal of the American Society for Information Science \& Technology 62(6) (June): 1118-1129. doi:10.1002/asi.21539. Accessed August 7, 2013.

MacRoberts, M.H., and B.R. MacRoberts. 2010. Problems of Citation Analysis: A Study of Uncited and Seldom-cited Influences. Journal of the American Society for Information Science and Technology 61 (1): 1-12. doi:10.1002/asi.21228.

McEntire, David, A. ed. 2007. Disciplines, Disasters, and Emergency Management: The Convergence and Divergence of Concepts, Issues and Trends from the Research Literature. Charles C. Thomas: Springfield, IL.

McGuire, Michael, and Deborah Schneck. 2010. What If Hurricane Katrina Had Hit in 2020? The Need for Strategic Management of Disasters. Public Administration Review. 70(s1) (December): s201-s207. doi: 10.1111/j.1540-6210.2010.02273.x. Accessed August 29, 2013.

Merriam-Webster. 2013. Merriam-Webster's Online Dictionary. Merriam-Webster, Inc. Accessed August 20, 2013. http://www.merriam-webster.com/info/copyright.htm.

Miletti, D.S. 1999. Disaster by Design: A Reassessment of Natural Disasters in the United States. Joseph Henry Press: Washington, D.C.

Moore, Melinda, Horacio R. Trujillo, Brooke K. Stearns, Ricardo Basurto-Davila, and David K. Evans. 2009. Learning from Exemplary Practices in International Disaster Management: A Fresh Avenue to Inform U.S. Policy? Journal of Homeland Security \& Emergency Management 6 (1) (January): 1-38. i3h. doi: 10.2202/1547-7355.1515. Accessed December 10, 2012.

Newman, Andy. 2012. "Hurricane Sandy Vs. Hurricane Katrina.” The New York Times, November 27, sec. City Room. http://cityroom.blogs.nytimes.com/2012/11/27/hurricane-sandy-vshurricane-katrina/. Accessed August 20, 2013.

Ngo, Ehren B. 2001. When Disasters and Age Collide: Reviewing Vulnerability of the Elderly. Natural Hazards Review 2(2): 80-89.

Osareh, Farideh. 1996. Bibliometrics, Citation Analysis and Co-Citation Analysis: A Review of Literature I. Libri 46 (3). doi:10.1515/libr.1996.46.3.149.

Oxford Dictionaries. 2013. Accessed August 20, 2013. http://oxforddictionaries.com/us/?utm_expid=53203432-7.nIZ06w4jQO6CBLpDJCQ4Mg.0.

Rubin, Claire, ed. 2012. Emergency Management: The American Experience, 1900-2010. 2nd ed. Boca Raton, FL: CRC Press. 
Rubin, Richard. 2010. Foundations of Library and Information Science. ALA Editions: Chicago, IL.

Sylves, Richard T. 2006. "President Bush and Hurricane Katrina: A Presidential Leadership Study.” Annals of the American Academy of Political \& Social Science 604 (March): 26-56. doi:10.1177/0002716205286066. Accessed December 12, 2012.

U.S. Department of Homeland Security. The College List Colleges, Universities and Institutions Offering Emergency Management Courses. 2013. The College List Colleges, Universities and Institutions Offering Emergency Management Courses. May 20. http://www.training.fema.gov/emiweb/edu/collegelist/. Accessed August 20, 2013.

U.S. Department of Commerce. National Oceanic and Atmospheric Administration. Hurricane. Katrina 2005. 2012. Hurricanes in History. May 30. http://www.nhc.noaa.gov/outreach/history/\#katrina. Accessed August 27, 2013.

U.S. Department of Commerce. National Oceanic and Atmospheric Administration. Emergency Management Degree Programs. 2013. Emergency Management. Accessed August 20, 2013. http://www.prh.noaa.gov/cphc/pages/FAQ/Hurricanes_vs_tornadoes.php.

U.S. Department of Commerce. National Oceanic and Atmospheric Administration. Hurricane Katrina National Oceanic and Atmospheric Administration National Climatic Data Center. 2005. December. http://www.ncdc.noaa.gov/extremeevents/specialreports/Hurricane-Katrina.pdf. Accessed August 27, 2013.

U.S. Department of Commerce. National Oceanic and Atmospheric Administration. Hurricane Wilma 2005. Hurricanes in History. http://www.nhc.noaa.gov/outreach/history/\#galveston. Accessed August 27, 2013.

U.S. Department of Commerce. National Oceanic and Atmospheric Administration. Hurricanes and Tornadoes. 2013. Accessed August 20.

http://www.prh.noaa.gov/cphc/pages/FAQ/Hurricanes_vs_tornadoes.php. Accessed August 27, 2013.

U.S. Department of Commerce. National Oceanic and Atmospheric Administration. Hurricanes in History. 2012. National Weather Service, National Hurrican Accessed August 27, 2013.e Center. May 30. http://www.nhc.noaa.gov/outreach/history/\#galveston.

U.S. Department of Commerce. National Oceanic and Atmospheric Administration. Hurricanes Rita 2005. Hurricanes in History. http://www.nhc.noaa.gov/outreach/history/\#galveston. Accessed August 27, 2013.

Wallace, Danny P. 1989. "Bibliometrics and Citation Analysis.” In Principles and Applications of Information Science for Library Professionals, edited by John N. Olsgaard, 10-26. Chicago: American Library Association. 
Was Superstorm Sandy Costlier Than Hurricane Katrina? 2012. Live Science. November 27. Accessed August 7, 2013. http://www.livescience.com/25076-sandy-katrina-cost.html.

Zhang, Li. 2007. Citation Analysis for Collection Development: A Study of International Relations Journal Literature. Library Collections, Acquisitions, and Technical Services 31 (3-4): 195-207. doi:10.1016/j.lcats.2007.11.001. 


\section{Appendix: Sample Articles}

Adams, Glenn, Laurie T. O’Brien, and Jessica C. Nelson. 2006.Perceptions of Racism in Hurricane Katrina: A Liberation Psychology Analysis. Analyses of Social Issues and Public Policy 6 (1): 215-235. doi:10.1111/j.1530-2415.2006.00112.x.

Adger, W. Neil, Terry P. Hughes, Carl Folke, Stephen R. Carpenter, and Johan Rockström. 2005.Social-Ecological Resilience to Coastal Disasters. Science 309 (5737) (August 12): 10361039. doi:10.1126/science.1112122.

Andrews, Steven, Haizhong Wang, Daiheng Ni, Song Gao, and John Collura. 2010.Development and Implementation of an Adapted Evacuation Planning Methodology in the Framework of Emergency Management and Disaster Response: A Case Study Using TransCAD. Journal of Transportation Safety \& Security 2 (4): 352-368. doi:10.1080/19439962.2010.517743.

Baker, Daniel, and Karen Refsgaard. 2007.Institutional Development and Scale Matching in Disaster Response Management. Ecological Economics 63 (2-3) (August 1): 331-343. doi:10.1016/j.ecolecon.2007.01.007.

Barry, Jm. 2006. Clinical Issues. What the 1918 Flu Pandemic Teaches Us: Yesterday’s Lessons Inform Today’s Preparedness. MLO: Medical Laboratory Observer 38 (9) (September): 26.

Basolo, Victoria, Laura J. Steinberg, Raymond J. Burby, Joyce Levine, Ana Maria Cruz, and Chihyen Huang. 2009.The Effects of Confidence in Government and Information on Perceived and Actual Preparedness for Disasters. Environment and Behavior 41 (3) (May 1): 338-364. doi:10.1177/0013916508317222.

Beidel, Bernard E. 2006.An Integrated Approach to Expand One Federal Government EAP’s Role Beyond Disaster Response. Journal of Workplace Behavioral Health 21 (3-4): 59-87. doi:10.1300/J490v21n03_04.

Belle, Deborah. 2006. Contested Interpretations of Economic Inequality Following Hurricane Katrina. Analyses of Social Issues and Public Policy 6 (1): 143-158. doi:10.1111/j.15302415.2006.00111.x. 
Bersch, Carren. 2010. Disasters: Where They Find Us. Clinical Chemistry and Laboratory Medicine 48 (5) (May 1): 599-602.

Birkland, Thomas A., and Sarah E. DeYoung. 2011.Emergency Response, Doctrinal Confusion, and Federalism in the Deepwater Horizon Oil Spill. Publius: The Journal of Federalism 41 (3) (July 1): 471-493. doi:10.1093/publius/pjr011.

Bish, Douglas R. 2011.Planning for a Bus-based Evacuation. OR Spectrum 33 (3) (July 1): 629-654. doi:10.1007/s00291-011-0256-1.

Blanchard-Boehm, R. Denise, and M. Jeffrey Cook. 2004. Risk Communication and Public Education in Edmonton, Alberta, Canada on the 10th Anniversary of the 'Black Friday' Tornado. International Research in Geographical and Environmental Education 13 (1): 38-54. doi:10.1080/10382040408668791.

Bloodworth, Donna Marie, C George Kevorkian, Edith Rumbaut, and Faye Y. Chiou-Tan. 2007. Impairment and Disability in the Astrodome after Hurricane Katrina: Lessons Learned About the Needs of the Disabled After Large Population Movements. American Journal of Physical Medicine \& Rehabilitation 86 (9) (September): 770-775. doi:10.1097/PHM.0b013e31813e0439.

Bowers, Paula J., Margaret Lynn Maguire, Patricia A. Silva, and Rhonda Kitchen. 2004.Everybody Out! Will Your Facility’s Evacuation Procedures Withstand a Disaster? Nursing Management 35 (4): 50-54.

Brezina, Timothy, and Herbert E. Phipps. 2009. False News Reports, Folk Devils, and the Role of Public Officials: Notes on the Social Construction of Law and Order in the Aftermath of Hurricane Katrina. Deviant Behavior 31 (1): 97-134. doi:10.1080/01639620902854803.

Brunner, Ronald D., Amanda H. Lynch, Jon C. Pardikes, Elizabeth N. Cassano, Leanne R. Lestak, and Jason M. Vogel. 2004. An Arctic Disaster and Its Policy Implications. Arctic 57 (4) (December 1): 336-346. doi:10.2307/40512638. 
Budek, A., M. Zain, L. Qiao, and R. Phelan. 2006. Validation of Finite-Element Analyses for Storm Shelters. Journal of Architectural Engineering 12 (2): 64-71. doi:10.1061/(ASCE)10760431(2006)12:2(64).

Burnett, Jason, Carmel Dyer, and Sabrina Pickins. 2007. Rapid Needs Assessments for Older Adults in Disasters. Generations 31 (4) (December 1): 10-15.

Burroughs, Stephen M., and Sarah F. Tebbens. 2005. Power-law Scaling and Probabilistic Forecasting of Tsunami Runup Heights. Pure and Applied Geophysics 162 (2) (February 1): 331-342. doi:10.1007/s00024-004-2603-5.

Caeti, Tory J., John Liederbach, and Steven S. Bellew. 2005. Police-media Relations at Critical Incidents: Interviews from Oklahoma City. International Journal of Police Science \& Management 7 (2) (May): 86-97. doi:10.1350/ijps.7.2.86.65776.

Camargo, Suzana J., and Adam H. Sobel. 2007. Workshop on Tropical Cyclones and Climate. Bulletin of the American Meteorological Society 88 (3) (March): 389-391. doi:10.1175/BAMS88-.-389.

Centers for Disease Control and Prevention (CDC). 2005. Infectious Disease and Dermatologic Conditions in Evacuees and Rescue Workers after Hurricane Katrina--multiple States, AugustSeptember, 2005. MMWR. Morbidity and Mortality Weekly Report 54 (38) (September 30): 961964.

Cetron, Marvin J., Fred J. Demicco, Robert R. Nelson, Warren L. Reuther, and John A. Williams. 2006. Convention Centers as Staging Grounds for Disaster Recovery. Journal of Convention \& Event Tourism 8 (4): 129-139. doi:10.1300/J452v08n04_09.

Chamlee-Wright, Emily, and Virgil Henry Storr. 2009.Club Goods and Post-Disaster Community Return. Rationality and Society 21 (4) (November 1): 429-458. doi:10.1177/1043463109337097.

Changnon, Stanley A. 2011. Temporal Distribution of Weather Catastrophes in the USA. Climatic Change 106 (2) (May 1): 129-140. doi:10.1007/s10584-010-9927-1. 
Cheung, K.F., A.C. Phadke, Y. Wei, R. Rojas, Y.J.-M. Douyere, C.D. Martino, S.H. Houston, et al. 2003. Modeling of Storm-induced Coastal Flooding for Emergency Management. Ocean Engineering 30 (11) (August): 1353-1386. doi:10.1016/S0029-8018(02)00133-6.

Christina Staudhammer, Francisco Escobedo, Alicia Lawrence, Mary Duryea, Pete Smith, and Mickey Merritt. 2011. Rapid Assessment of Change and Hurricane Impacts to Houston’s Urban Forest Structure. Arboriculture \& Urban Forestry 37 (2): 60-66.

Chua, Alton Y.K., Selcan Kaynak, and Schubert S.B. Foo. 2007. An Analysis of the Delayed Response to Hurricane Katrina through the Lens of Knowledge Management. Journal of the American Society for Information Science and Technology 58 (3): 391-403. doi:10.1002/asi.20521.

Chuang, Hwei-Lin, and Wei-Chiao Huang. 2007. A Re-Examination of the Suicide Rates in Taiwan. Social Indicators Research 83 (3) (September 1): 465-485. doi:10.1007/s11205-006-9056-4.

Cigler, Beverly A. 2009. Post-Katrina Hazard Mitigation on the Gulf Coast. Public Organization Review 9 (4) (December 1): 325-341. doi:10.1007/s11115-009-0095-6.

Clukey, Lory. 2010. Transformative Experiences for Hurricanes Katrina and Rita Disaster Volunteers. Disasters 34 (3): 644-656. doi:10.1111/j.1467-7717.2010.01162.x.

Colvard, Michael D., Lewis N. Lampiris, Geoffrey A. Cordell, James James, Albert Guay, Moses Lee, Catherine M. Stokes, and Gregory Scott. 2006. The Dental Emergency Responder Expanding the Scope of Dental Practice. The Journal of the American Dental Association 137 (4) (April 1): 468-473.

Comfort, Louise K. 2006. Cities at Risk Hurricane Katrina and the Drowning of New Orleans. Urban Affairs Review 41 (4) (March 1): 501-516. doi:10.1177/1078087405284881.

Corey, Christy M., and Elizabeth A. Deitch. 2011. Factors Affecting Business Recovery Immediately after Hurricane Katrina. Journal of Contingencies and Crisis Management 19 (3): 169-181. doi:10.1111/j.1468-5973.2011.00642.x. 
Cox, Robert, Teresa Amundson, and Bruce Brackin. 2008. Evaluation of the Patterns of Potentially Toxic Exposures in Mississippi Following Hurricane Katrina. Clinical Toxicology 46 (8) (January): 722-727. doi:10.1080/15563650701455379.

Dach-Gruschow, Karl, and Ying-yi Hong. 2006. The Racial Divide in Response to the Aftermath of Katrina: A Boundary Condition for Common Ingroup Identity Model. Analyses of Social Issues and Public Policy 6 (1): 125-141. doi:10.1111/j.1530-2415.2006.00110.x.

Danna, Denise, Marirose Bernard, John Jones, and Pamela Mathews. 2009. Improvements in Disaster Planning and Directions for Nursing Management: JONA: The Journal of Nursing Administration 39 (10) (October): 423-431. doi:10.1097/NNA.0b013e3181b9224b.

Denis, Claude. 2007. Canadians in Trouble Abroad: Citizenship, Personal Security, and North American Regionalization. Politics \& Policy 35 (4): 648-663. doi:10.1111/j.17471346.2007.00078.x.

Denning, Peter J. 2006. Hastily Formed Networks. Communications of the ACM 49 (4) (April): 1519. doi:10.1145/1139922.1139936.

Denning, Peter J., and Rick Hayes-Roth. 2006. Decision Making in Very Large Networks. Commun. ACM 49 (11) (November): 19-23. doi:10.1145/1167838.1167852.

Dobalian, Aram, Maria Claver, and Jacqueline J. Fickel. 2010. Hurricanes Katrina and Rita and the Department of Veterans Affairs: A Conceptual Model for Understanding the Evacuation of Nursing Homes. Gerontology 56 (6): 581-588. doi:10.1159/000302713.

Doerfel, Marya L., Chih-Hui Lai, and Lisa V. Chewning. 2010. The Evolutionary Role of Interorganizational Communication: Modeling Social Capital in Disaster Contexts. Human Communication Research 36 (2): 125-162. doi:10.1111/j.1468-2958.2010.01371.x.

Donner, William, and Havidán Rodríguez. 2008. Population Composition, Migration and Inequality: The Influence of Demographic Changes on Disaster Risk and Vulnerability. Social Forces 87 (2) (December 1): 1089-1114. doi:10.1353/sof.0.0141. 
Douglas, V. 2007. Education and Development. Developing Disaster Management Modules: a Collaborative Approach. British Journal of Nursing 16 (9) (May 10): 526-529.

Drezner, Tammy. 2004. Location of Casualty Collection Points. Environment and Planning C: Government and Policy 22 (6): 899 - 912. doi:10.1068/c13r.

Ducy, Elizabeth McAdams, and Laura M. Stough. 2011. Exploring the Support Role of Special Education Teachers After Hurricane Ike Children With Significant Disabilities. Journal of Family Issues 32 (10) (October 1): 1325-1345. doi:10.1177/0192513X11412494.

Dynes, Russell R. 2003. Noah and Disaster Planning: The Cultural Significance of the Flood Story. Journal of Contingencies and Crisis Management 11 (4): 170-177. doi:10.1111/j.09660879.2003.01104003.x.

Eisenman, David P., Cheryl Wold, Jonathan Fielding, Anna Long, Claude Setodji, Scot Hickey, and Lillian Gelberg. 2006. Differences in Individual-Level Terrorism Preparedness in Los Angeles County. American Journal of Preventive Medicine 30 (1) (January): 1-6. doi:10.1016/j.amepre.2005.09.001.

Farazmand, Ali. 2009. Hurricane Katrina, the Crisis of Leadership, and Chaos Management: Time for Trying the 'Surprise Management Theory in Action.' Public Organization Review 9 (4) (December 1): 399-412. doi:10.1007/s11115-009-0099-2.

Fonseca, Daniel J., Gary P. Moynihan, Jordan Johnston, and Jordan Jennings. 2009. A Simulation Tool for Hurricane Evacuation Planning. Journal of Modelling and Simulation in Engineering 2009 (January): 10:1-10:8. doi:10.1155/2009/729570.

Freudenburg, William R., Robert Gramling, Shirley Laska, and Kai T. Erikson. 2008. Organizing Hazards, Engineering Disasters? Improving the Recognition of Political-Economic Factors in the Creation of Disasters. Social Forces 87 (2) (December 1): 1015-1038. doi:10.1353/sof.0.0126.

Froede, Carl R. 2010. Constructed Sand Dunes on the Developed Barrier-Spit Portion of Dauphin Island, Alabama (U.S.A). Journal of Coastal Research 264 (July): 699-703. doi:10.2112/JCOASTRES-D-09-00028.1. 
Gaddis, Erica Brown, Brian Miles, Stephanie Morse, and Debby Lewis. 2007. Full-cost Accounting of Coastal Disasters in the United States: Implications for Planning and Preparedness. Ecological Economics 63 (2-3) (August 1): 307-318. doi:10.1016/j.ecolecon.2007.01.015.

Garnett, James, and Alexander Kouzmin. 2009. Crisis Communication Post Katrina: What Are We Learning? Public Organization Review 9 (4) (December 1): 385-398. doi:10.1007/s11115-0090096-5.

Gheytanchi, Anahita, Lisa Joseph, Elaine Gierlach, Satoko Kimpara, Jennifer Housley, Zeno E. Franco, and Larry E. Beutler. 2007. The Dirty Dozen: Twelve Failures of the Hurricane Katrina Response and How Psychology Can Help. American Psychologist 62 (2): 118-130. doi:10.1037/0003-066X.62.2.118.

Gill, Duane A. 2007. Secondary Trauma or Secondary Disaster? Insights from Hurricane Katrina. Sociological Spectrum 27 (6): 613-632. doi:10.1080/02732170701574941.

Groscurth, Christopher R. 2011. Paradoxes of Privilege and Participation: The Case of the American Red Cross. Communication Quarterly 59 (3): 296-314. doi:10.1080/01463373.2011.583498.

Grove, Kevin. 2012. Preempting the Next Disaster: Catastrophe Insurance and the Financialization of Disaster Management. Security Dialogue 43 (2) (April 1): 139-155. doi:10.1177/0967010612438434.

Hasan, S., S. Ukkusuri, H. Gladwin, and P. Murray-Tuite. 2011. Behavioral Model to Understand Household-Level Hurricane Evacuation Decision Making. Journal of Transportation Engineering 137 (5): 341-348. doi:10.1061/(ASCE)TE.1943-5436.0000223.

Henderson, Tammy L., and Gladys Hildreth. 2011. Experiences in the Face of Disasters Children, Teachers, Older Adults, and Families. Journal of Family Issues 32 (10) (October 1): 1277-1284. doi:10.1177/0192513X11412488.

Hilgartner, Stephen. 2007. Overflow and Containment in the Aftermath of Disaster. Social Studies of Science 37 (1) (February 1): 153-158. doi:10.2307/25474507. 
Iqbal, Shahed, Jacquelyn H. Clower, Sandra A. Hernandez, Scott A. Damon, and Fuyuen Y. Yip. 2012. A Review of Disaster-Related Carbon Monoxide Poisoning: Surveillance, Epidemiology, and Opportunities for Prevention. American Journal of Public Health 102 (10) (October): 19571963. doi:10.2105/AJPH.2012.300674.

Ivers, Louise C, and Edward T Ryan. 2006. Infectious Diseases of Severe Weather-related and Floodrelated Natural Disasters: Current Opinion in Infectious Diseases 19 (5) (October): 408-414. doi:10.1097/01.qco.0000244044.85393.9e.

Jia, Hongzhong, Fernando Ordóñez, and Maged Dessouky. 2007. A Modeling Framework for Facility Location of Medical Services for Large-scale Emergencies. IIE Transactions 39 (1): 4155. doi:10.1080/07408170500539113.

Kapucu, Naim. 2008. Collaborative Emergency Management: Better Community Organising, Better Public Preparedness and Response. Disasters 32 (2): 239-262. doi:10.1111/j.14677717.2008.01037.x.

Kasapoglu, Aytül, and Mehmet Ecevit. 2004. Comparative Behavioral Response to Future Earthquakes: The Cases of Turkey and USA. Social Behavior and Personality: An International Journal 32 (4): 373-382. doi:10.2224/sbp.2004.32.4.373.

Kearns, Faith R., Noah C. Goldstein, Brent Pedersen, and Max A. Moritz. 2008. The Fire Information Engine. Journal of Map \& Geography Libraries 4 (1): 195-206. doi:10.1300/J230v04n01_13.

Keenan, Heather T, Stephen W Marshall, Mary Alice Nocera, and Desmond K Runyan. 2004. Increased Incidence of Inflicted Traumatic Brain Injury in Children after a Natural Disaster. American Journal of Preventive Medicine 26 (3) (April): 189-193. doi:10.1016/j.amepre.2003.10.023.

Kim, Son Chae, Ruth Plumb, Quynh-Nga Gredig, Larry Rankin, and Barbara Taylor. 2008. Mediumterm post-Katrina Health Sequelae Among New Orleans Residents: Predictors of Poor Mental and Physical Health. Journal of Clinical Nursing 17 (17): 2335-2342. doi:10.1111/j.13652702.2008.02317.x. 
Kleinfeld, Margo. 2007. Misreading the Post-tsunami Political Landscape in Sri Lanka: The Myth of Humanitarian Space. Space and Polity 11 (2): 169-184. doi:10.1080/13562570701722030.

Kleinpeter, Myra A. 2007. Shifts in Dialysis Patients from Natural Disasters in 2005. Hemodialysis International 11: S33-S37. doi:10.1111/j.1542-4758.2007.00227.x.

Lachlan, Kenneth A., Jennifer Burke, Patric R. Spence, and Donyale Griffin. 2009. Risk Perceptions, Race, and Hurricane Katrina. Howard Journal of Communications 20 (3): 295-309. doi:10.1080/10646170903070035.

Laditka, Sarah B., James N. Laditka, Sudha Xirasagar, Carol B. Cornman, Courtney B. Davis, and Jane V.E. Richter. 2008. Providing Shelter to Nursing Home Evacuees in Disasters: Lessons From Hurricane Katrina. American Journal of Public Health 98 (7) (July): 1288-1293. doi:10.2105/AJPH.2006.107748.

Lafuente, Corazon R., Veronica Eichaker, Vernon E. Chee, and Eleanor Chapital. 2007. Post-Katrina Provision of Health Care to Veterans in a Mobile Clinic: Providers' Perspectives. Journal of the American Academy of Nurse Practitioners 19 (8): 383-391. doi:10.1111/j.17457599.2007.00241.x.

Lamanna, Zhanna, Kim H. Williams, and Carla Childers. 2012. An Assessment of Resilience: Disaster Management and Recovery for Greater New Orleans' Hotels. Journal of Human Resources in Hospitality \& Tourism 11 (3): 210-224. doi:10.1080/15332845.2012.668653.

Lee, Tsung-Lin. 2008. Prediction of Storm Surge and Surge Deviation Using a Neural Network. Journal of Coastal Research 4 (July): 76-82. doi:10.2112/07-0830.1.

Lezama, Nicholas G., Lawrence M. Riddles, William A. Pollan, and Leonardo C. Profenna. 2011. Disaster Aeromedical Evacuation. Military Medicine 176 (10): 1128-1132.

Li, Hongfei, L.A. Treinish, and J. R M Hosking. 2010. A Statistical Model for Risk Management of Electric Outage Forecasts. IBM Journal of Research and Development 54 (3): 8:1-8:11. doi:10.1147/JRD.2010.2044836. 
Li, Maotang, H.D. Cheng, and Yejun Wang. 2007. Novel Airborne Real-Time Survey System. IEEE Transactions on Instrumentation and Measurement 56 (6): 2404-2410. doi:10.1109/TIM.2007.907952.

Licina, Derek. 2011. Disaster Preparedness Formalizing a Comparative Advantage for the Department of Defense in U.S. Global Health and Foreign Policy. Military Medicine 176 (11): 1207-1211.

Loucks, D., J. Stedinger, and E. Stakhiv. 2006. Individual and Societal Responses to Natural Hazards. Journal of Water Resources Planning and Management 132 (5): 315-319. doi:10.1061/(ASCE)0733-9496(2006)132:5(315).

Lowry, William. 2006. Potential Focusing Projects and Policy Change. Policy Studies Journal 34 (3): 313-335. doi:10.1111/j.1541-0072.2006.00175.x.

Mathbor, Golam M. 2007. Enhancement of Community Preparedness for Natural Disasters The Role of Social Work in Building Social Capital for Sustainable Disaster Relief and Management. International Social Work 50 (3) (May 1): 357-369. doi:10.1177/0020872807076049.

Mayer, Bradley W., Jimmy Moss, and Kathleen Dale. 2008. Disaster and Preparedness: Lessons from Hurricane Rita. Journal of Contingencies and Crisis Management 16 (1): 14-23. doi:10.1111/j.1468-5973.2008.00531.x.

McTaggart-Cowan, Ron, Lance F. Bosart, John R. Gyakum, and Eyad H. Atallah. 2007. Hurricane Katrina (2005). Part I: Complex Life Cycle of an Intense Tropical Cyclone. Monthly Weather Review 135 (12) (December): 3905-3926. doi:10.1175/2007MWR1875.1.

Michel-Kerjan, Erwann. 2003. New Challenges in Critical Infrastructures: A US Perspective. Journal of Contingencies and Crisis Management 11 (3): 132-141. doi:10.1111/1468-5973.1103008.

Miles, Brian, and Stephanie Morse. 2007. The Role of News Media in Natural Disaster Risk and Recovery. Ecological Economics 63 (2-3) (August 1): 365-373. doi:10.1016/j.ecolecon.2006.08.007. 
Miller-Hooks, Elise, and Theodor Krauthammer. 2007. An Intelligent Evacuation, Rescue and Recovery Concept. Fire Technology 43 (2) (June 1): 107-122. doi:10.1007/s10694-006-8433-5.

Monahan, Torin. 2006. Securing the Homeland: Torture, Preparedness, and the Right to Let Die. Social Justice 33 (1 (103)) (January 1): 95-105. doi:10.2307/29768354.

Morgan, Oliver W, Pongruk Sribanditmongkol, Clifford Perera, Yeddi Sulasmi, Dana Van Alphen, and Egbert Sondorp. 2006. Mass Fatality Management Following the South Asian Tsunami Disaster: Case Studies in Thailand, Indonesia, and Sri Lanka. PLoS Med 3 (6) (June 6): e195. doi:10.1371/journal.pmed.0030195.

Moynihan, Donald P. 2012. Extra-Network Organizational Reputation and Blame Avoidance in Networks: The Hurricane Katrina Example. Governance 25 (4): 567-588. doi:10.1111/j.14680491.2012.01593.x.

Naghawi, Hana, and Brian Wolshon. 2010. Transit-Based Emergency Evacuation Simulation Modeling. Journal of Transportation Safety \& Security 2 (2): 184-201. doi:10.1080/19439962.2010.488316.

Nelson, Arthur C., and Steven P. French. 2002. Plan Quality and Mitigating Damage from Natural Disasters: A Case Study of the Northridge Earthquake with Planning Policy Considerations. Journal of the American Planning Association 68 (2): 194-207. doi:10.1080/01944360208976265.

Nepal, Vishnu, Deborah Banerjee, Mark Perry, and Deborah Scott. 2012. Disaster Preparedness of Linguistically Isolated Populations Practical Issues for Planners. Health Promotion Practice 13 (2) (March 1): 265-271. doi:10.1177/1524839910384932.

Palacio, H, U Shah, C Kilborn, D Martinez, V Page, T Gavagan, K Mattox, et al. 2005. Norovirus Outbreak Among Evacuees from Hurricane Katrina --- Houston, Texas, September 2005. MMWR. Morbidity and Mortality Weekly Report 54 (40) (October 14): 1016-1018.

Paul, Bimal Kanti. 2006. Disaster Relief Efforts: An Update. Progress in Development Studies 6 (3) (July 1): 211-223. doi:10.1191/1464993406ps139oa. 
Paul, Jomon Aliyas, and Govind Hariharan. 2012. Location-allocation Planning of Stockpiles for Effective Disaster Mitigation. Annals of Operations Research 196 (1) (July 1): 469-490. doi:10.1007/s10479-011-1052-7.

Peguero, Anthony A. 2006. Latino Disaster Vulnerability The Dissemination of Hurricane Mitigation Information Among Florida's Homeowners. Hispanic Journal of Behavioral Sciences 28 (1) (February 1): 5-22. doi:10.1177/0739986305284012.

Perry, Ronald W., and Michael K. Lindell. 2003. Preparedness for Emergency Response: Guidelines for the Emergency Planning Process. Disasters 27 (4): 336-350. doi:10.1111/j.03613666.2003.00237.x.

Peterson, Cheryl A. 2006. Be Safe, Be Prepared: Emergency System for Advance Registration of Volunteer Health Professionals in Disaster Response.” OJIN: Online Journal of Issues in Nursing 11 (3) (September 30): Manuscript 2. doi:10.3912/OJIN.Vol11No03Man02.

Phadke, Amal C., Christopher D. Martino, Kwok Fai Cheung, and Samuel H. Houston. 2003. Modeling of Tropical Cyclone Winds and Waves for Emergency Management. Ocean Engineering 30 (4) (March): 553-578. doi:10.1016/S0029-8018(02)00033-1.

Pietrzak, Robert H., Melissa Tracy, Sandro Galea, Dean G. Kilpatrick, Kenneth J. Ruggiero, Jessica L. Hamblen, Steven M. Southwick, and Fran H. Norris. 2012. Resilience in the Face of Disaster: Prevalence and Longitudinal Course of Mental Disorders Following Hurricane Ike. PLoS ONE 7 (6) (June 26): e38964. doi:10.1371/journal.pone.0038964.

Powell, Tia, Dan Hanfling, and Lawrence O. Gostin. 2012. Emergency Preparedness and Public Health: The Lessons of Hurricane Sandy. JAMA Journal of the American Medical Association 308 (24): 2569-2570.

Pyles, Loretta. 2011. Neoliberalism, INGO Practices and Sustainable Disaster Recovery: a postKatrina Case Study. Community Development Journal 46 (2) (April 1): 168-180. doi:10.1093/cdj/bsp058.

Quarantelli, Enrico L. 2008. Conventional Beliefs and Counterintuitive Realities. Social Research 75 (3) (October 1): 873-904. doi:10.2307/40972095. 
Rabito, Felicia A., Shahed Iqbal, Sara Perry, Whitney Arroyave, and Janet C. Rice. 2012. Environmental Lead after Hurricane Katrina: Implications for Future Populations. Environmental Health Perspectives 120 (2) (February): 180-184. doi:10.1289/ehp.1103774.

Ramsey, Elijah, Dirk Werle, Zhong Lu, Amina Rangoonwala, and Yukihiro Suzuoki. 2009. A Case of Timely Satellite Image Acquisitions in Support of Coastal Emergency Environmental Response Management. Journal of Coastal Research 255 (September): 1168-1172. doi:10.2112/JCOASTRES-D-09-00012.1.

Rawls, Carmen G., and Mark A. Turnquist. 2011. Pre-positioning Planning for Emergency Response with Service Quality Constraints. OR Spectrum 33 (3) (July 1): 481-498. doi:10.1007/s00291011-0248-1.

Renne, John L., Thomas W. Sanchez, and Todd Litman. 2011. Carless and Special Needs Evacuation Planning A Literature Review. Journal of Planning Literature 26 (4) (November 1): 420-431. doi:10.1177/0885412211412315.

Reyes, Augustina H. 2010. The Immigrant Children of Katrina. Peabody Journal of Education 85 (4): 443-468. doi:10.1080/0161956X.2010.518037.

Runyan, Rodney C. 2006. Small Business in the Face of Crisis: Identifying Barriers to Recovery from a Natural Disaster1. Journal of Contingencies and Crisis Management 14 (1): 12-26. doi:10.1111/j.1468-5973.2006.00477.x.

Salloum, Alison, Paulette Carter, Berre Burch, Abbe Garfinkel, and Stacy Overstreet. 2011. Impact of Exposure to Community Violence, Hurricane Katrina, and Hurricane Gustav on Posttraumatic Stress and Depressive Symptoms Among School Age Children. Anxiety, Stress \& Coping 24 (1): 27-42. doi:10.1080/10615801003703193.

Schmalzried, Hans, and L. Jr Flemming Fallon. 2007. Succession Planning for Local Health Department Top Executives: Reducing Risk to Communities. Journal of Community Health 32 (3) (June): 169-180. doi:10.1007/s10900-006-9044-2. 
Schrecker, Ted. 2010. Human Rights Against the Global Marketplace. Global Social Policy 10 (2) (July 21): 154-158. doi:10.1177/14680181100100020102.

Sellnow, Timothy L., Matthew W. Seeger, and Robert R. Ulmer. 2002. Chaos Theory, Informational Needs, and Natural Disasters. Journal of Applied Communication Research 30 (4): 269-292. doi:10.1080/00909880216599.

Sisson, S. A., L. R. Pericchi, and S. G. Coles. 2006. A Case for a Reassessment of the Risks of Extreme Hydrological Hazards in the Caribbean. Stochastic Environmental Research and Risk Assessment 20 (4) (May 1): 296-306. doi:10.1007/s00477-005-0246-4.

Smith, Steven Lee. 2012. Coping with Disaster: Lessons Learned From Executive Directors of Nonprofit Organizations (NPOs) in New Orleans Following Hurricane Katrina. Administration in Social Work 36 (4): 359-389. doi:10.1080/03643107.2011.604401.

Sommers, Samuel R., Evan P. Apfelbaum, Kristin N. Dukes, Negin Toosi, and Elsie J. Wang. 2006. Race and Media Coverage of Hurricane Katrina: Analysis, Implications, and Future Research Questions. Analyses of Social Issues and Public Policy 6 (1): 39-55. doi:10.1111/j.15302415.2006.00103.x.

Stehling-Ariza, Tasha, Yoon Soo Park, Jonathan J. Sury, and David Abramson. 2012. Measuring the Impact of Hurricane Katrina on Access to a Personal Healthcare Provider: The Use of the National Survey of Children's Health for an External Comparison Group. Maternal and Child Health Journal 16 (1) (April 1): 170-177. doi:10.1007/s10995-012-1006-y.

Stehr, Steven D. 2006. The Political Economy of Urban Disaster Assistance. Urban Affairs Review 41 (4) (March 1): 492-500. doi:10.1177/1078087405284887.

Strathdee, Steffanie A., Julie A. Stachowiak, Catherine S. Todd, Wael K. Al-Delaimy, Wayne Wiebel, Catherine Hankins, and Thomas L. Patterson. 2006. Complex Emergencies, HIV, and Substance Use: No ‘Big Easy’ Solution. Substance Use \& Misuse 41 (10-12) (January): 16371651. doi:10.1080/10826080600848116. 
Tanner, Andrea, Daniela B. Friedman, Alexis Koskan, and Daphney Barr. 2009. Disaster Communication on the Internet: A Focus on Mobilizing Information. Journal of Health Communication 14 (8): 741-755. doi:10.1080/10810730903295542.

Thirion, Xavier, David Debensason, Jean Christophe Delarozière, and Jean Louis San Marco. 2005. August 2003: Reflections on a French Summer Disaster. Journal of Contingencies and Crisis Management 13 (4): 153-158. doi:10.1111/j.1468-5973.2005.00471.x.

Tuason, Ma. Teresa G., C. Dominik, and Lynne Carroll. 2012. The Disaster Continues: A Qualitative Study on the Experiences of Displaced Hurricane Katrina Survivors. Professional Psychology: Research and Practice 43 (4): 288-297. doi:10.1037/a0028054.

Urbina, Elba, and Brian Wolshon. 2003. National Review of Hurricane Evacuation Plans and Policies: a Comparison and Contrast of State Practices. Transportation Research Part A: Policy and Practice 37 (3) (March): 257-275. doi:10.1016/S0965-8564(02)00015-0.

VanVactor, Jerry D. 2011. Health Care Logistics: Who Has the Ball During Disaster? Emerging Health Threats Journal 4 (May 10). doi:10.3402/ehtj.v4i0.7167. http://www.ncbi.nlm.nih.gov/pmc/articles/PMC3168225/.

Voracek, Martin, and Gernot Sonneck. 2002.Suicide After Natural Disasters and Statistical Disasters: A Comment. Archives of Suicide Research 6 (4): 399-401. doi:10.1080/13811110214529.

W Williams, J Guarisco, K Guillot, J Wales, C Revels, G Barre, K Stevens, et al. 2005. Surveillance for Illness and Injury After Hurricane Katrina --- New Orleans, Louisiana, September 8--25, 2005. JAMA Journal of the American Medical Association 294 (22) (December 14): 2837-2839. doi:10.1001/jama.294.22.2837.

Wang, Feng, Chao Li, Xuesong Zhou, Mahesh Nayak, and Xiaoming Chen. 2010. Effectiveness of Traffic Management Strategies at Destination During Emergency Evacuation. Journal of Transportation Safety \& Security 2 (2): 152-170. doi:10.1080/19439962.2010.487784.

Wells, Michael E. 2006. Psychotherapy for Families in the Aftermath of a Disaster. Journal of Clinical Psychology 62 (8): 1017-1027. doi:10.1002/jclp.20286. 
Whalen, T., S. Gopal, and D. Abraham. 2004. Cost-Benefit Model for the Construction of Tornado Shelters. Journal of Construction Engineering and Management 130 (6): 772-779. doi:10.1061/(ASCE)0733-9364(2004)130:6(772).

Whitworth, Paul M. 2006. Continuity of Operations Plans: Maintaining Essential Agency Functions When Disaster Strikes. Journal of Park and Recreation Administration 24 (4) (October 18). http://js.sagamorepub.com/jpra/article/view/1394.

Ye, Zhirui, Jaydeep Chaudhari, Janelle Booth, and Benedict Posadas. 2010. Evaluation of the Use of Rural Transportation Infrastructure in Evacuation Operations. Journal of Transportation Safety \& Security 2 (2): 88-101. doi:10.1080/19439962.2010.487633.

Zotti, Marianne E., and Amy M. Williams. 2011. Reproductive Health Assessment After Disaster: Introduction to the RHAD Toolkit. Journal of Women's Health 20 (8) (August): 1123-1127. doi:10.1089/jwh.2011.3021. 